Amsterdam Expeditions to the West Indian Islands, Report 22*)

\title{
A NEW SPECIES OF PSAMMOGAMMARUS (CRUSTACEA, AMPHIPODA) FROM THE ROQUES ARCHIPELAGO, VENEZUELA
}

\author{
by \\ JAN H. STOCK \\ Institute of Taxonomic Zoology, University of Amsterdam, P.O. Box 20125, 1000 HC Amsterdam, \\ The Netherlands
}

\section{SUMMARY}

Psammogammarus scopulorum n. sp. is described from Bekebe key in the Roques archipelago. The new species was found in coral debris, in a seepage behind a rubble bar.

\section{RÉSUMÉ}

Psammogammarus scopulorum n. sp. est décrit d'un îlot corallien, Bekebe, dans l'Archipel des Roques. La nouvelle espèce a été trouvée parmi les débris madréporiques, dans un suintement derrière une barrière de gravats.

\section{INTRODUCTION}

In a previous paper (Stock, 1982: 195), the presence of an undescribed species of the genus Psammogammarus S. Karaman, 1955, in the Roques archipelago, has been recorded.

Only one other species of this genus, Ps. caesicolus Stock, 1980, is known from the West Indies, viz. from anchihaline waters of Curaçao (Netherlands Antilles). The present species is markedly different from Ps. caesicolus, and from the four other species attributed to Psammogammarus (see Stock, 1980: 383) as well, justifying the erection of a new species for the material from Los Roques.

\section{Psammogammarus scopulorum n. sp.}

Material. - Amsterdam Expeditions to the West Indian Islands, sta. 82-51, Los Roques (Venezuela), seepage on leeward side of coarse sand and coral debris bar of a

*) Report 21 has been published in Bijdr. Dierk., 52 (2): 228-230 (1982). small key called Bekebe $\left(11^{\circ} 51^{\prime} 22^{\prime \prime} \mathrm{N} 66^{\circ} 56^{\prime} 02^{\prime \prime} \mathrm{W}\right.$ ) (fig. 21); phreatobiological pump (method Bou-Rouch), 701 of water filtered; temperature $28.2^{\circ} \mathrm{C}$; chlorinity $17056 \mathrm{mg} / 1$; April 4, 1982.

One female, in non-reproductive stage (oöstegites not setose), holotype (Zoölogisch Museum Amsterdam coll. no. ZMA Amph. 107.569a, b, c).

Description. - Holotype, length (frontal margin cephalon to tip of telson) $1.7 \mathrm{~mm}$; third uropod $577 \mu \mathrm{m}$. Unpigmented, blind.

First antenna (fig. 1) with rather swollen basal segment; segment 2 slender and narrow, shorter than segment 1 ; segment 3 more than half as long as segment 2. Flagellum 8 -segmented, segment 1 elongate, about $3 / 4$ of the length of the 3rd peduncle segment. Remaining flagellum segments also rather slender; long aesthetasks (as long as or slightly longer than the corresponding segments) on segments 4 through 7. Accessory flagellum 2-segmented, distinctly shorter than the first flagellum segment.

Second antenna (fig. 2) shorter than the first. Gland cone strong. Peduncle segments 4 and 5 scantily setose. Flagellum 6-segmented; first flagellum segment long, almost half as long as peduncle segment 5 .

Upper lip (fig. 3) roughly rhomboidal.

Mandible (fig. 4) with 5 spines between the pars molaris and the pars incisiva. The pars molaris consists of 2 blades; the innermost of these is finely denticulated on the left mandible, and armed with 3 coarse teeth on the right one. Palp 3-segmented; basal segment small, unarmed; second segment the longest, armed 


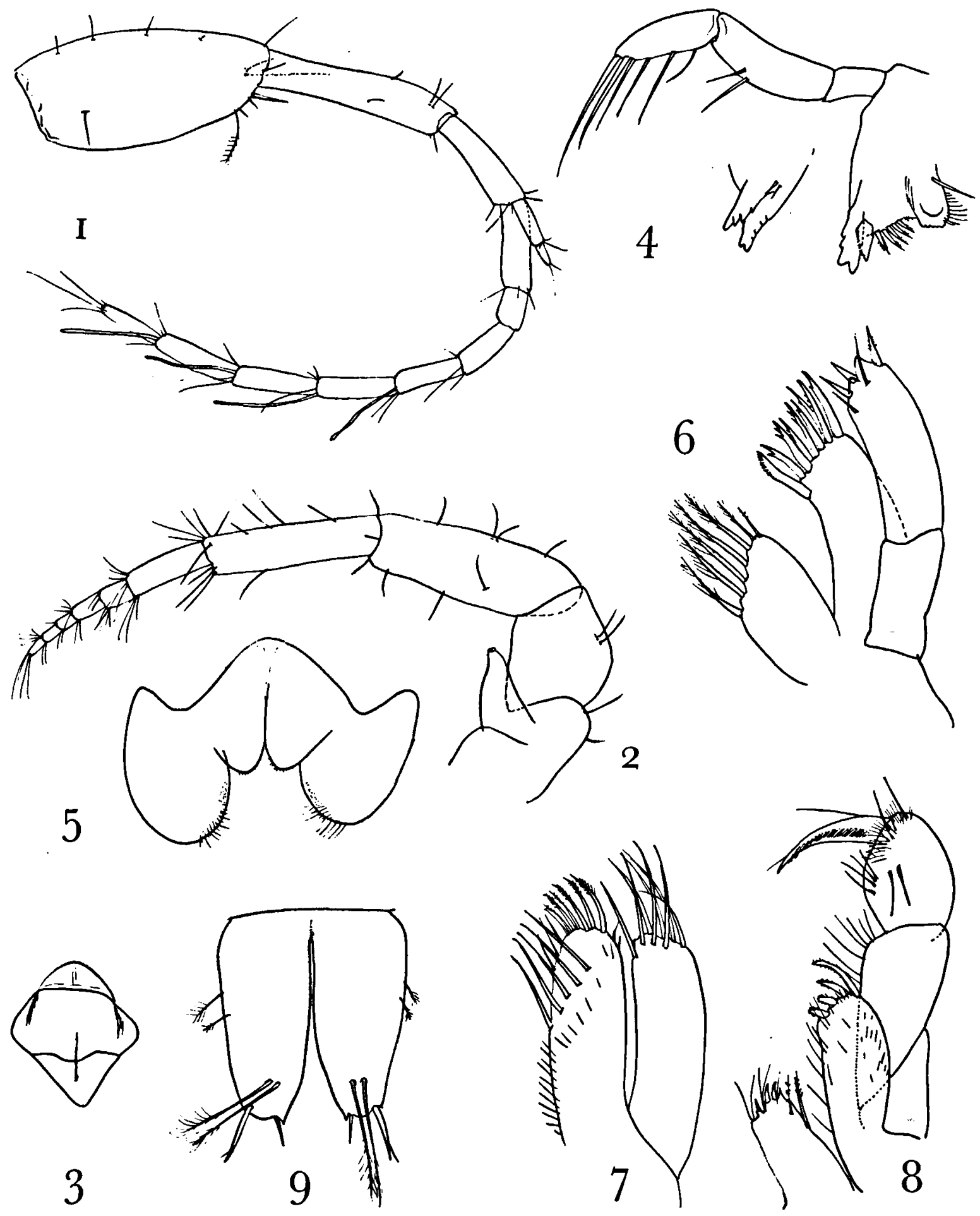

Figs. 1-9. Psammogammarus scopulorum n. sp., $\$$ holotype: 1, first antenna (scale ab); 2, second antenna (ab); 3, upper lip (ac); 4, left mandible and pars molaris of right mandible (ac); 5, lower lip (ac); 6, first maxilla (ad); 7, second maxilla (ad); 8, maxilliped (ac); 9, telson (ac). (For scales see next figure.) 
with 2 ventral setae; third segment having about $4 / 5$ of the length of the second, armed with 3 long ventral setae and 3 long distal setae.

Lower lip (fig. 5) with large, ciliated outer lobes and well-developed inner lobes.

First maxilla (fig. 6) with 2-segmented palp; distal armature of palp consisting of 3 spines and 2 setae. Outer lobe with 9 spines, the innermost armed with a row of fine teeth, the others with 1 (rarely 2 or 3 ) medial teeth. The inner lobe is longer than wide, distally armed with 7 plumose setae.

Second maxilla (fig. 7) consisting of an outer lobe with 8 distal setae and of an inner lobe with 6 barbed distal setae, a mediodistal row of 4 naked setae, and an oblique row of 5 naked setae.

Maxilliped (fig. 8) with short inner lobe (armed with 2 plumose setae, 3 spines, and 5 setules). Outer lobe with 3 shorter and 1 longer distal spines. Distal palp segment swollen; claw slender, long.

First gnathopod (fig. 10) with trapezoidal coxal plate, the anterior corner of which is bluntly rounded. Propodus with 2 palmar angle spines; palm not very oblique, armed with some 5 small palmar spines.

Second gnathopod (fig. 11) larger than the first. Coxal plate subrectangular, much wider than long. Coxal gill sausage-shaped, longer than the basis. Carpus trapezoidal, at least as long as wide. Propodus ovate, with 1 bifid palmar angle spine; palmar margin convex, with about 5 small spines of a size. Claw rather short.

Oöstegites linear.

Coxal plates 3 and 4 (figs. 12 and 13) much wider than long. Pereiopods 3 and 4 similar in shape, very poorly armed. Propodal sole with 2 setae only. Claw very thin, straight. Coxal gills with short basal stalk, ovate, large (almost as long as the basis).

Fifth pereiopod (fig. 14) with an elongate, non-lobate basis; posterior margin with 3 spinules; posterodistal corner with 2 setae. Distal segments not very elongate, armature very scanty.
Sixth pereiopod (fig. 15) with a small, ovate coxal gill. Basis elongate, non-lobate; posterior margin slightly convex, armed with 4 spinules. The three long distal segments armed with a low number of long, almost setiform, spines.

Seventh pereiopod (fig. 16) only partially preserved: the distal segments are lacking. The basis is slightly more rectangular than in P6; posteroventral corner rounded; posterior margin armed with 5 spinules only.

Epimeral plates 1 and 2 ending in an inconspicuous posteroventral point; plate 3 distinctly pointed (fig. 20).

First uropod (fig. 17) with 1 basofacial spine; a long spine is implanted at the basis of the endopodite. Exopodite without marginal spines, endopodite with 1 marginal spine.

Second uropod (fig. 18) with subequal rami; both rami with a row of minute spinules.

Third uropod (fig. 19) with 2-segmented exopodite, both segments of equal length; armature consisting of a low number of long spines. Endopodite monomerous, almost as long as segment 1 of the exopodite.

Telson (fig. 9) almost entirely cleft; lateral margin with 2 short plumose setae; distal margin with a small spiniform process, a longer lateral and a shorter medial spine. Two very long, plumose ("sensory") setae are implanted dorsally, at a slight distance of the tip.

Derivatio nominis. - The proposed specific name, scopulorum, is the genetive plural of the Latin word scopulus, thus meaning "from the rocks", alluding to the type-locality, the Roques archipelago.

Comparison with other species. - The present new species has a very long endopodite of the third uropod. The only other species of Psammogammarus in which this endopodite is as long as the first segment of the exopodite is Ps. longiramus (Stock Nijssen, 1965), found in a salty well in the Dahlak archipelago (Red Sea). In the other species, the endopodite is shorter than segment 1 of the exopodite (in Ps. caesicolus Stock, 1980 , about $75 \%$, in Ps. coecus S. 


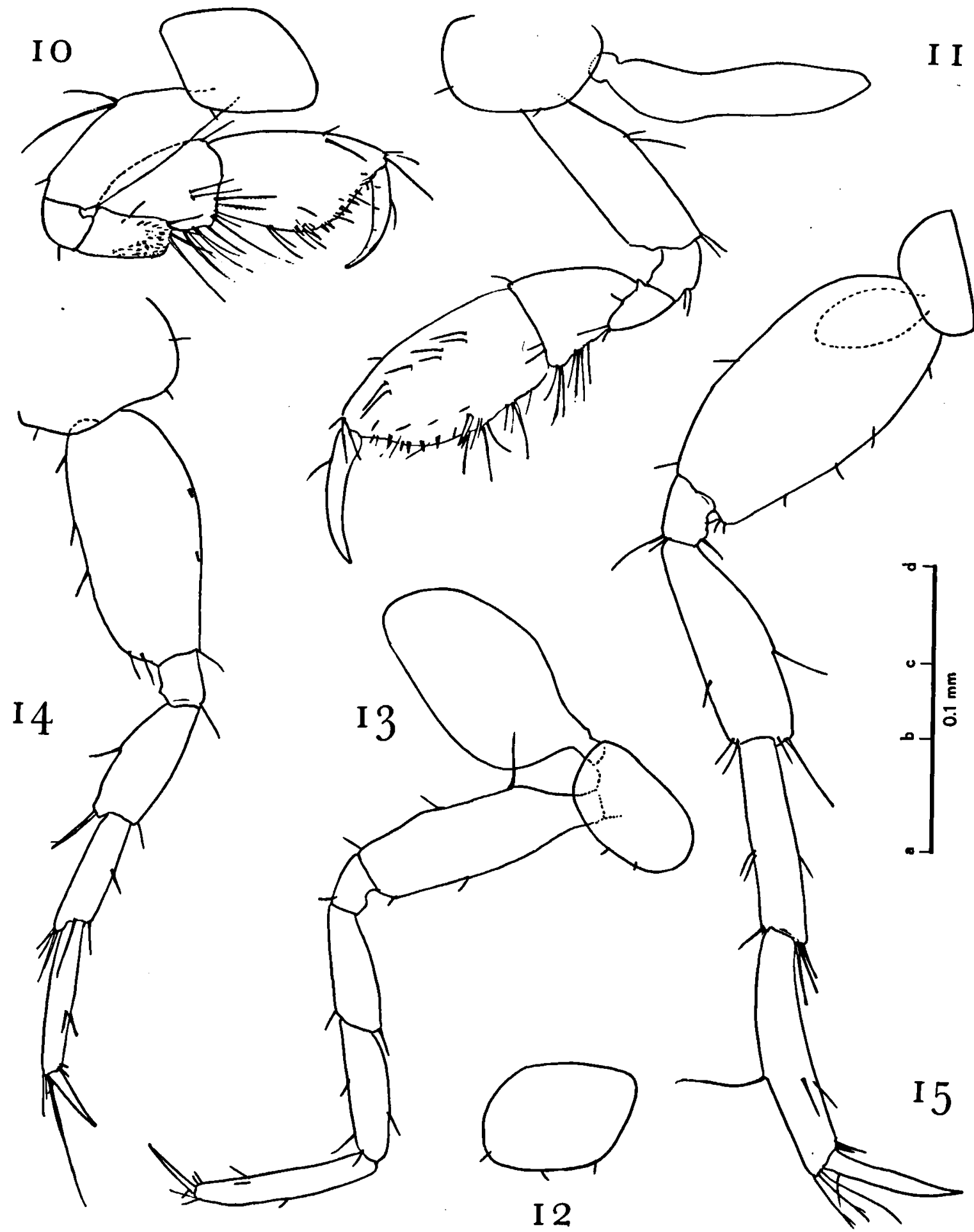

Figs. 10-15. Psammogammarus scopulorum n. sp., \& holotype: 10, first gnathopod (scale ab); 11, second gnathopod (ab); 12, coxal plate of third pereiopod (ab); 13, fourth pereiopod (ab); 14, fifth pereiopod (ab); 15, sixth pereiopod (ab). 

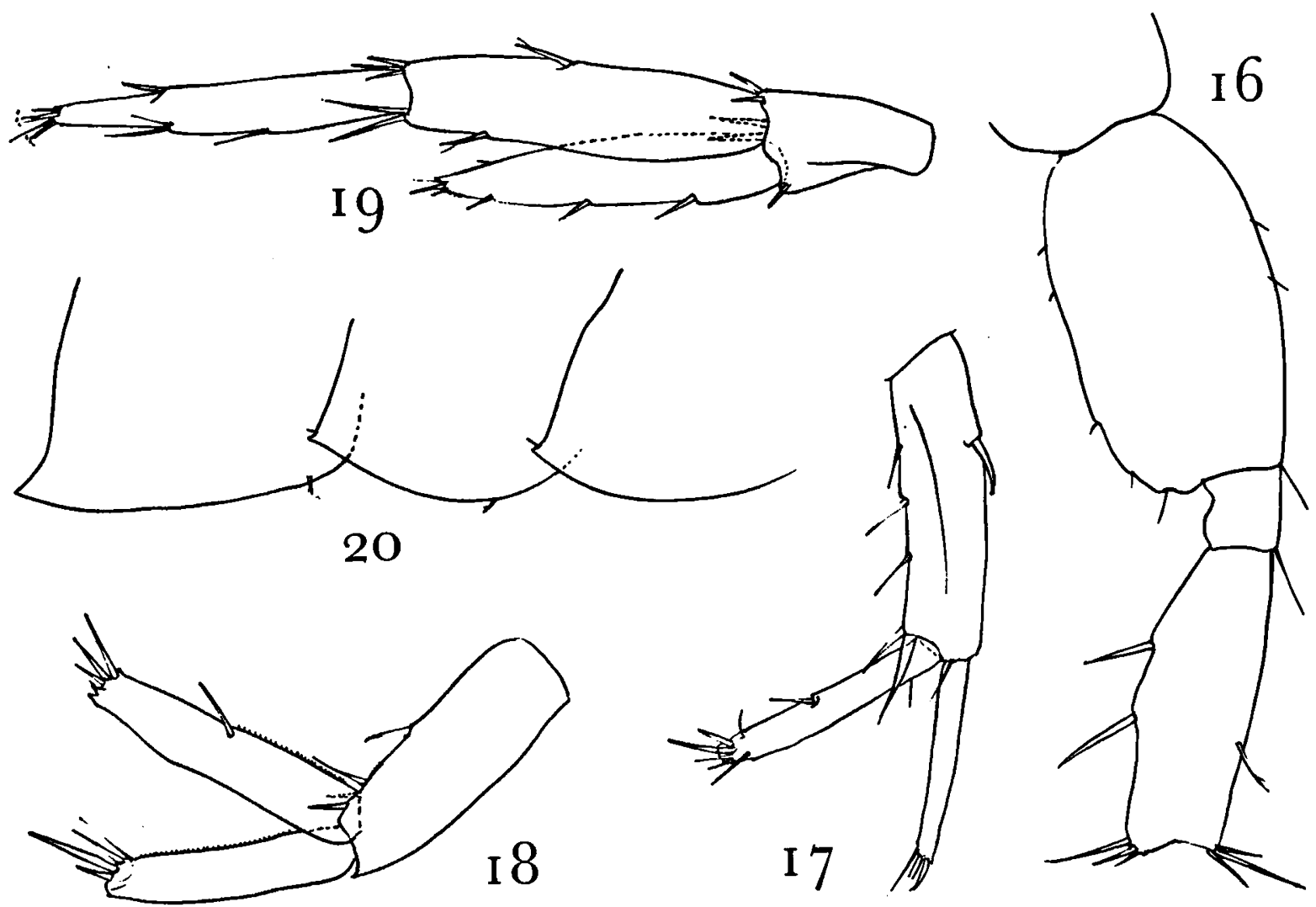

Figs. 16-20. Psammogammarus scopulorum n. sp., $\$$ holotype: 16, basal portion of seventh pereiopod (scale ab); 17, first uropod (ab); 18, second uropod (ac); 19, third uropod (ab); 20, epimeral plates 1 to 3, from the right (ab). (For scales see previous figure.)

Karaman, 1955, about $50 \%$, in Ps. garthi (Barnard, 1952) about $33 \%$, and in Ps. gracilis (Ruffo \& Schiecke, 1976) about $20 \%$ ).

The differences with Ps. longiramus are numerous (inner lobe of $\mathrm{Mx} 1$ is wider than long, armed with about 15 distal setae; the 2 nd exopodite segment of uropod 3 is less elongate; the telson has laterobasal spines instead of setae; a longer accessory flagellum of A1; more richly armed pereiopods 3 through 7).

It might be useful to enumerate also the differences (in addition to the shorter Ur3 endopodite) with the only other West Indian representative of the genus Psammogammarus, Ps. caesicolus, from anchihaline waters in Curaçao. The 3rd peduncular segment of A1 of Ps. caesicolus is much less elongate; the first flagellar segment of $\mathrm{A} 1$ is short; the coxal plates
1 to 4 are almost as long as wide; the palmar angle spines of P2 are longer; the coxal gills of P2 through P4 are much smaller; the propodus of P3 and P4 is more richly armed; the basis of $\mathrm{P} 5$ is less elongate; the posterior margin of the basis of P5 through P7 is armed with numerous setules; the telson bears lateral spines instead of setae; the posteroventral corner of the 3rd epimere is not produced into a sharp point.

\section{ACKNOWLEDGEMENTS}

The fieldwork in the Roques archipelago has been financially supported by the Treub Maatschappij (Utrecht), the Beijerinck-Popping Fonds (Amsterdam), the Amsterdamse Universiteits Vereniging (Amsterdam) and the University of Amsterdam. The sampling of Los Roques has been carried out by Dr. Steven Weinberg, Mrs. Francisca Zijlstra, and the author. 


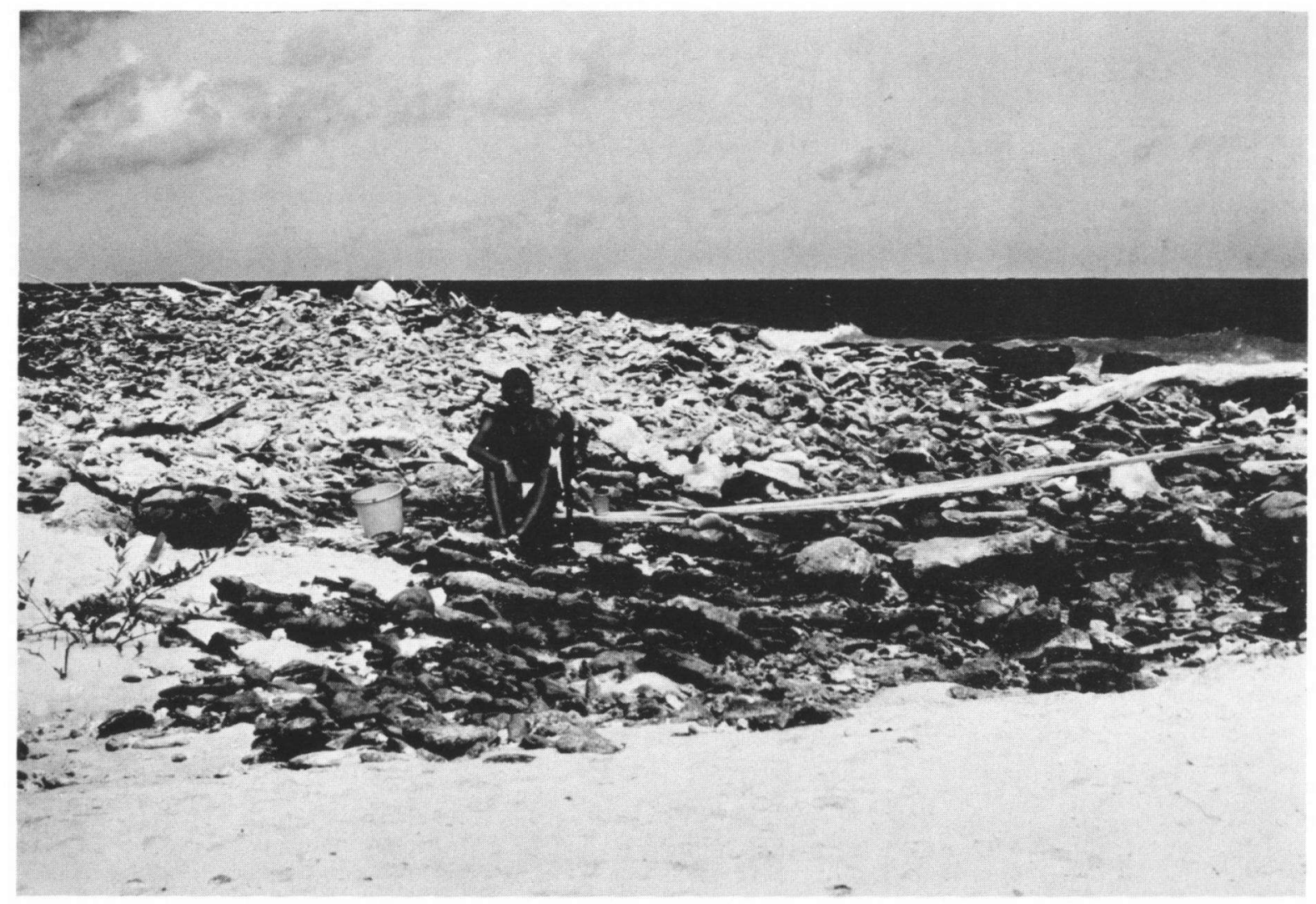

Fig. 21. Type-locality of Psammogammarus scopulorum n. sp., the rubble wall at Bekebe key. Dr. Steven Weinberg (centre) handles the phreatobiological pump. (Black and white print of Kodachrome slide.)

Many thanks are due to Drs. Roger Laughlin and Ernesto Weil, of the Fundación Cientifica Los Roques (Caracas), for many services rendered, such as air transportation to the islands, inter-insular boat transportation, and in particular for their hospitality in the foundation's facilities on Dos Mosquesos island.

The organization of the fieldwork in Venezuela has greatly benefited from support rendered by H. M. Embassy of The Netherlands, Caracas, in particular by Dr. Ir. Th. P. M. de Wit, Agricultural Attaché.

\section{REFERENCES}

Barnard, J. L., 1952. A new species of amphipod from Lower California (genus Eriopisa). Pacif. Sci., 6: 295-299.

Karaman, S. L., 1955. Über einige Amphipoden des
Grundwassers der jugoslavischen Meeresküste. Acta Mus. maced. Sci. nat., 2 (11/22): 223-241.

Ruffo, S. \& U. Schiecke, 1976. Descrizione di Eriopisa gracilis n. sp. (Amphipoda, Gammaridae) delle coste di Malta e ridescrizione di E. coeca (S. Karaman, 1955) (= E. peresi M. Ledoyer, 1968). Boll. Mus. civ. Stor. nat. Verona, 2: 415-438.

Stock, J. H., 1980. Amsterdam Expeditions to the West Indian Islands, Report 8. A new cave amphipod (Crustacea) from Curaçao: Psammogammarus caesicolus n. sp. Bijdr. Dierk., 50 (2): 375-386.

- - 1982. Amsterdam Expeditions to the West Indian Islands, Report 18. Stygobiont Crustacea Malacostraca from geologically older and younger Antillean islands: a biogeographical analysis. Bijdr. Dierk., 52 (2): 191-199.

Stock, J. H. H. Nijssen, 1965. Eriopisa longiramus n. sp., a new subterranean amphipod from a Red Sea island. Bull. Sea Fish. Res. Stn. Haifa, 38: 28-39. 